\title{
OPTICAL DATING OF ALLUVIAL DEPOSITS AT THE OROGENIC FRONT OF THE ANDEAN PRECORDILLERA (MENDOZA, ARGENTINA)
}

\author{
SILKE SCHMIDT ${ }^{1}$, SUMIKO TSUKAMOTO ${ }^{2}$, ERIC SALOMON $^{1}$, MANFRED FRECHEN $^{2}$, RALF HETZEL $^{1}$ \\ ${ }^{1}$ Institut für Geologie und Paläontologie, Westfälische Wilhelms-Universität Münster, \\ Corrensstraße 24, Münster, 48149, Germany. \\ ${ }^{2}$ Leibniz Institute for Applied Geophysics, Stilleweg 2, 30655 Hannover, Germany.
}

Received 2 February 2010

Accepted 22 July 2011

\begin{abstract}
Well constrained numerical ages of alluvial fan sediments are key to understanding the chronology of alluvial episodes and tectonic activity at the front of the Andean Precordillera. We tested the application of radiocarbon and optically stimulated luminescence (OSL) dating in the distal part of an alluvial fan five kilometers north of Mendoza. For OSL dating a large number of aliquots $(n>70)$ - each composed of $\sim 50$ quartz grains - were measured in order to obtain reliable burial ages despite scattered dose distributions. Owing to a feldspar contamination in all samples, an infrared stimulation was inserted before each OSL measurement, which reduced the feldspar OSL signal successfully. By using the minimum age model we obtained stratigraphically consistent burial ages of alluvial deposits in a depth profile. The uppermost $\sim 1 \mathrm{~m}$ of sediment is composed of debris flow deposits buried $770 \pm 76$ years ago. Three plant remnants used for radiocarbon dating from the same layer, however, yielded ages younger than 350 years, which are interpreted to underestimate the depositional age. Underneath the debris flow, a major unconformity cuts a series of distal alluvial fan sediments with interstratified floodplain deposits, which are composed of sandy and calcite-rich silt layers, respectively. Three samples from this unit which were distributed over one meter of sediment thickness yielded statistically concordant OSL ages of $12.3 \pm 1.2 \mathrm{ka}, 12.3 \pm 1.2 \mathrm{ka}$, and $11.7 \pm 1.1 \mathrm{ka}$. The deposition of these sediments during the latest Pleistocene coincides with a phase of cool and humid climate, which occurred before the alluvial fan propagated farther into the foreland. The overlying debris flow sediments are associated with alluvial fan incision during the arid Late Holocene.
\end{abstract}

Keywords: OSL dating, alluvial fan sediments, incomplete bleaching, minimum age model, Andean Precordillera.

\section{INTRODUCTION}

The mountain front of the Andean Precordillera in Argentina $\left(28-33^{\circ} \mathrm{S}\right.$, Fig. 1a) is characterized by alluvial fans and sequences of well-preserved terraces that were formed by fan incision. Detailed mapping and numerical age constraints are essential for understanding related sedimentary processes and recent tectonic activity, especially since debris flows and earthquakes are a threat to the one million inhabitants of Mendoza. As the city was built on top of alluvial fan sediments of unknown age, it is essential to establish their chronology to assess future hazards. The same accounts for several other landscapes and cities, since most mountain ranges feature sedimentation in alluvial fans over wide areas.

Corresponding author: S. Schmidt

e-mail: silkeschmidt@uni-muenster.de 
Several different dating methods can be applied to date alluvial fan sediments, e.g. radiocarbon, ${ }^{40} \mathrm{Ar}{ }^{39} \mathrm{Ar}$, uranium series, surface exposure, and optically stimulated luminescence (OSL) dating (e.g. Walker, 2005; Preusser et al., 2008). Radiocarbon and ${ }^{40} \mathrm{Ar} /{ }^{39} \mathrm{Ar}$ dating are analytically the most precise techniques, however, their application requires adequate materials (i.e. buried organic matter or volcanic material, respectively) that are not always available in alluvial sediments. Uranium series approaches require chemically unaltered carbonate, and analytical limits of surface exposure dating appear for young surfaces due to lacking accumulation of cosmogenic nuclides. OSL dating presumes the complete resetting of the optical signal during exposure to sunlight directly before the deposition. Although significant progress has been made on each of these approaches during the past decades, only six studies revealed consistent ages between OSL, ${ }^{14} \mathrm{C},{ }^{10} \mathrm{Be}$ and uranium series dating on alluvial, fluvial and playa sediments (Preusser et al., 2003; Anders et al., 2005; DeLong and Arnold, 2007; Magee et al., 2009; Kurth et al., 2011; Schmidt et al., 2011a). On the other hand, the alluvial sediments studied by Nissen et al. (2009) obtained significantly older ages from a ${ }^{10} \mathrm{Be}$ depth profile compared to those obtained from OSL techniques, although both methods revealed internally consistent results. Similar problems exist in fluvial and playa sediments dated by Folz et al. (2001), Cupper (2006), and Owen et al. (2007) who obtained only partly consistent ages when applying 2-5 dif-
Discrepancies in age estimates have also been reported when only one dating method is applied. For example, several studies obtained outlying OSL ages in profiles through alluvial sediments (e.g. Robinson et al., 2005; Sohn et al., 2007; Sancho et al., 2008). Other studies report OSL ages in alluvial sediments which are entirely consistent with the stratigraphic order, indicating that inconsistencies are not a general problem of the dating technique (e.g. Porat et al., 1996; Toms et al., 2004; Fattahi et al., 2006; Porat et al., 2010). Several authors mentioned that an overestimation of OSL ages may be the result of incomplete bleaching, i.e. an insufficient exposure to sunlight to reset the OSL signal during sedimentary transport (e.g. Stokes et al., 2001; Wallinga, 2002; Jain et al., 2004; Rodnight et al., 2006; Rittenour, 2008; Lauer et al., 2010). This problem can be diminished by using quartz instead of feldspar (Wallinga, 2002; Porat et al., 2009; Reimann et al., 2011), measuring only a few grains per aliquot, analyzing even single grains (e.g. Olley et al., 1999; Wallinga, 2002; Thomas et al., 2005; Rittenour, 2008; Porat et al., 2009), and/or applying an adequate model to extract the "true" burial age (Galbraith and Green, 1990; Bailey and Arnold, 2006; Arnold et al., 2007; Arnold and Roberts, 2009). ferent dating methods. This implies that the accuracy of these dating methods strongly depends on local circumstances, such as available material, age range, and accessibility of sampling locations (e.g. depth profile).

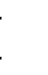

.
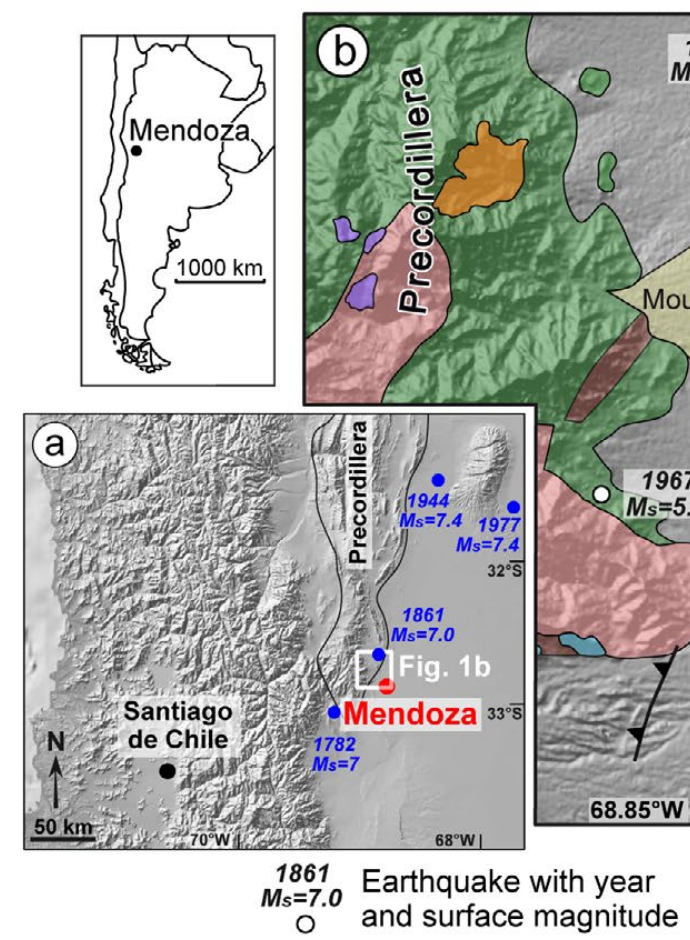


\section{.}


In this study we dated alluvial sediments using OSL and radiocarbon techniques in order to constrain the timing of alluvial fan development at the front of the Andean Precordillera. Owing to the young age of the studied deposits and the absence of volcanic ash layers and suitable carbonate coatings, it was not possible to apply exposure dating, ${ }^{40} \mathrm{Ar} r{ }^{39} \mathrm{Ar}$ dating, and uranium series dating.

\section{GEOLOGY OF THE STUDY AREA AND SAM- PLING SITES}

The study area is located directly north of Mendoza city, in the vicinity of the suburb Las Heras that was built on alluvial dan sediments from the Precordillera (Fig. 1b). A large alluvial fan adjacent to the north, namely $\mathrm{T}_{4}$, has been incised by ephemeral streams resulting in the formation of three lower terrace levels $T_{1}$ to $T_{3}$ (Fig. 2). The terrace deposits consist of alluvial sediments with a wide grain size spectrum ranging from silt to large cobbles, implying that sediment transport occurred mainly by debris flows. The subrounded clasts consist of different lithologies exposed in the Precordillera, including greenish Devonian sand- and siltstones, reddish Triassic sandstones and conglomerates and Miocene andesite (Fig. 1b). The terraces are cut by the Cal thrust fault which offsets $\mathrm{T}_{1}-\mathrm{T}_{4}$ by 0.8 to $8 \mathrm{~m}$ vertically (Schmidt et al., 2011b). The active surface $\mathrm{T}_{0}$ is not displaced since it postdates the last surface rupturing earthquake which

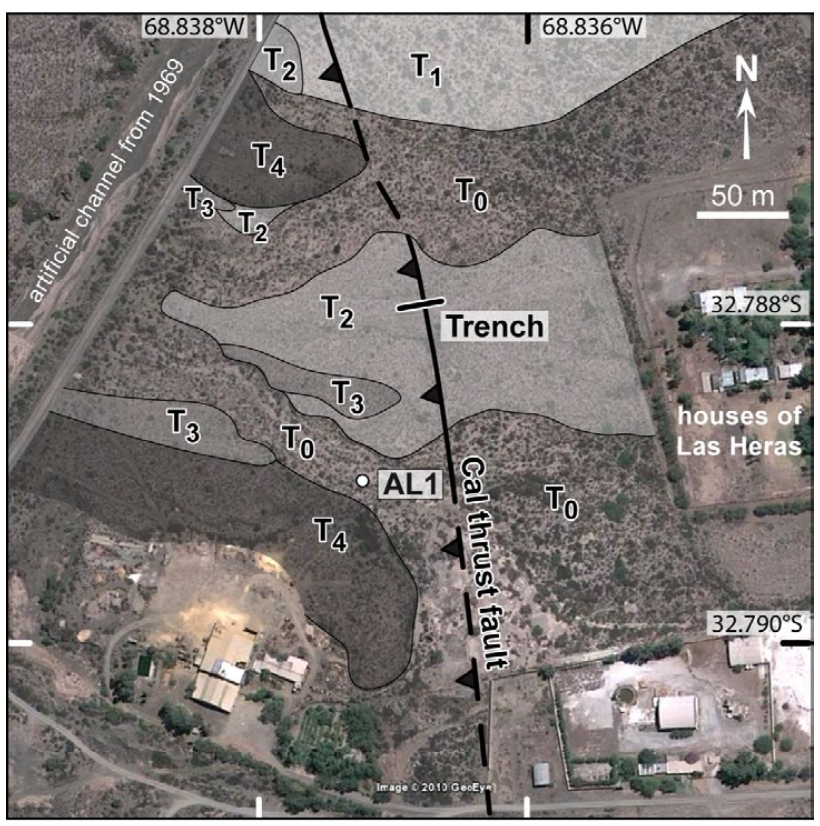

Fig. 2. Geological interpretation of the study area (satellite image taken by GeoEye in 2010, Google Earth). The unmapped area to the east and south has been modified by human activity. The OSL sample AL1 was taken from surface $T_{0}$, which indicates active erosion and sedimentation. All other OSL and the radiocarbon samples were collected in the trench (see Fig. 3). occurred in 1861 with a magnitude of $\mathrm{M}_{\mathrm{S}}=7.0$ (Mingorance, 2006) (Fig. 1b). One sample for OSL dating (AL1; Fig. 2) was collected in the deepest incised channel of this surface where a $\sim 25 \mathrm{~cm}$ thick sand lens is intercalated in clast-supported fluvial sediments.

Four other OSL samples (AL2 to AL5) were taken from a trench section that was excavated on terrace $T_{2}$ across the fault scarp generated by the Cal fault (Figs. 2, 3). The trench exhibits mainly coarse gravel deposits referred to as unit 1 , but also a sequence of fine-grained thin-layered strata named unit 2 , which is situated below a prominent erosional unconformity (Fig. 3a). Unit 1 consists of debris flow deposits and fluvial sediments, which slightly vary in color, grain size and the amount of clasts. The clasts are dominated by subrounded pebbles and cobbles, mostly of Devonian siltstones. In the eastern part of the trench, one layer shows cross-bedding stratification and imbricated clasts indicating an east-directed sediment transport (Fig. 3a). OSL sample AL2 and three radiocarbon samples were taken from this unit (Fig. 3).

Unit 2 is composed of slightly consolidated $1-10 \mathrm{~cm}$ thick layers of fine-grained sand and granule (Fig. 3a). The sediment is matrix supported and only $\sim 10 \%$ of its volume is composed of pebbles. Several pale yellow layers are conspicuous due to their higher resistance against erosion (layer type 4; Fig. 3). They are composed of calcite-rich silt with minor coarse-grained sand and rare pebble clasts. OSL samples in unit 2 derive from three different layers (Fig. 3). Samples AL3 and AL5 belong to layer type 2, which is composed of fine-grained sand with only a few pebbles. Sample AL4 was taken from coarse-grained sand with a large amount of granule (layer type 5).

All layers indicate significant deformation by folds and faults, for example unit 1 is deformed by three eastvergent folds (Fig. 3a). Likewise, the strata of unit 2 have experienced east-vergent folding and several small thrust faults offset the folded layers with displacements of several centimeters up to a few decimeters (Fig. 3a). Four colluvial wedges are exposed in the trench section (Fig. 3a), which were formed shortly after different earthquakes (Salomon, 2010). In the following, this manuscript focuses on the methodological aspects of numerical dating. A detailed description and interpretation of the tectonic features in the trench will be presented in a separate contribution.

\section{OSL DATING}

Mineral separation for OSL dating was undertaken at the Leibniz Institute for Applied Geophysics in Hannover (Germany) following the laboratory preparation procedures outlined in Aitken (1985) and Alappat et al. (2010). The 100 to $150 \mu \mathrm{m}$ size fraction was separated by dry sieving and treatment with hydrochloric acid, sodium oxalate and hydrogen peroxide. A quartz-rich fraction was then separated using sodium polytungstate 

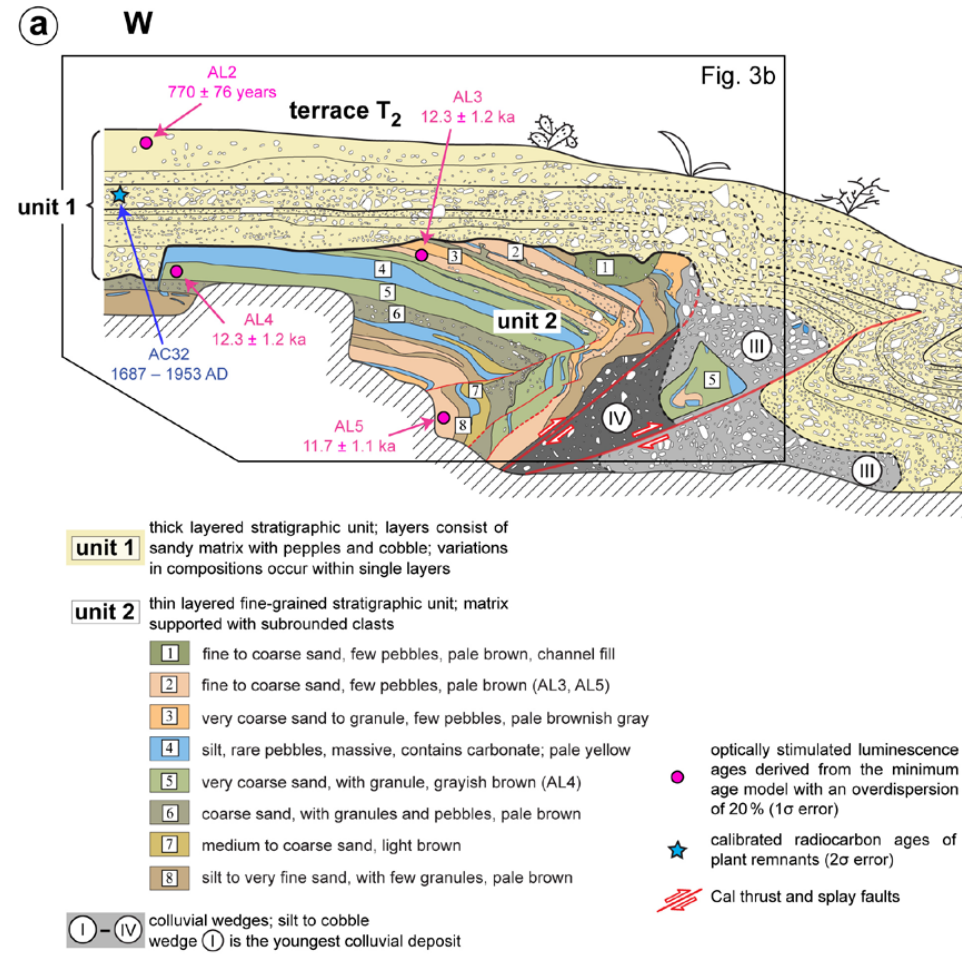

ages derived from the minimum age model with an overdispersio calibrated radiocarbon ages of श्. Cal thrust and splay faults

colluvial wedges, silt to cobble

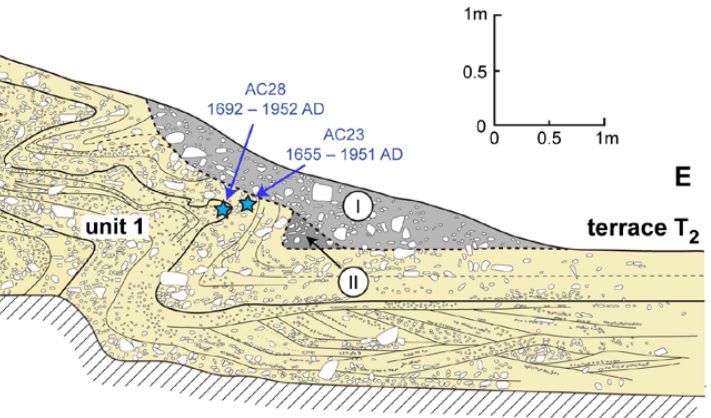

Fig. 3. (a) Geological interpretation of the trench with ages obtained by OSL and radiocarbon dating. The folded fine-grained layers of unit 2 are cut by erosion and are unconformably overlain by coarse-grained sediments of unit 1 . The four colluvial wedges are probably related to four earthquakes. (b) The photograph covers the area marked by the black square in Fig. 3a. The inclined light-colored horizons correspond to layer type 4 in unit 2.

$(2.62<\rho<2.70)$. To remove feldspar impurities and the alpha-irradiated surface, the quartz-rich fraction was etched in concentrated hydrofluoric acid (HF) for one hour. However, after HF etching all quartz fractions still showed an infrared stimulated luminescence (IRSL) signal, indicating remaining feldspar grains. Nevertheless, a second HF etching step was not performed since the first HF leaching dissolved already $80-90 \%$ of the fraction. Finally, the etched quartz was sieved a second time to the target grain size fraction of 100 to $150 \mu \mathrm{m}$.

All samples were mounted on $9.8 \mathrm{~mm}$ diameter stainless-steel discs using silicone oil. Medium-sized aliquots $(6 \mathrm{~mm})$ were used for preheat and dose recovery tests, while all further measurements were undertaken on small aliquots which are composed of approximately 50 grains each. OSL measurements were performed on a Risø TL/OSL-DA-15 reader equipped with a ${ }^{90} \mathrm{Sr} /{ }^{90} \mathrm{Y}$ beta source (Bøtter-Jensen et al., 2003). The luminescence detection for quartz was filtered with a UV band pass HOYA U-340 filter, which has a transmission in the range of $270-380 \mathrm{~nm}$.

\section{Dose rate}

The luminescence signal arises from natural radiation induced by the decay of the radioactive isotopes within the uranium and thorium decay chains, the decay of potassium, as well as a minor contribution of cosmogenic radiation (e.g. Prescott and Hutton, 1988; Olley et al., 1996). The samples for the dose rate calculation were collected in the surroundings of the luminescence samples up to a distance of $5 \mathrm{~cm}$. For each sample $700 \mathrm{~g}$ of dried sediment was measured in a Marinelli-beaker by high-resolution gamma-ray spectroscopy with a HighPurity Germanium N-type coaxial detector. The Marinelli-beakers were sealed and stored for a minimum of four weeks to enable the attainment of ${ }^{222} \mathrm{Rn}$ equilibrium. Because of degassing in nature, the radon loss was assumed to be in the order of $20 \pm 10 \%$ ( $1 \sigma$ uncertainty, Olley et al., 1996). The dose rate conversion factors were taken from Adamiec and Aitken (1998) and beta attenuation factors from Mejdahl (1979). To account for uncertainties related to beta attenuation, conversion factors, calibration of the gamma detector, and effects of past disequilibrium, we added a systematic error of $\pm 8 \%$ (cf. Olley et al., 1996; Murray and Olley, 2002). The results are summarized in Table 1.

The cosmic radiation depends mainly on geomagnetic latitude, altitude, and sample depth. Its contribution to the dose rate was calculated by the approach of Prescott and Stephan (1982) and Prescott and Hutton (1994). As recommended by Niedermann (2002), geographic coordi- 
Table 1. Natural dose rates of quartz for the five luminescence samples. All errors are $1 \sigma$ estimates.

\begin{tabular}{|c|c|c|c|c|c|c|c|c|}
\hline \multirow[t]{2}{*}{ Sample ID } & \multirow[t]{2}{*}{ Locality } & \multirow{2}{*}{$\begin{array}{l}\text { Depth } \\
\text { (m) }\end{array}$} & \multirow{2}{*}{$\begin{array}{c}\text { Water } \\
\text { content }^{\mathrm{a}}(\%)\end{array}$} & \multicolumn{3}{|c|}{ Radionuclides } & \multirow{2}{*}{$\begin{array}{c}\text { Cosmic dose } \\
D_{c} \text { (Gy/ka) }\end{array}$} & \multirow{2}{*}{$\begin{array}{c}\text { Total dose rate }^{\mathrm{b}} \\
D_{\text {tot }}(\mathrm{G} / \mathrm{ka})\end{array}$} \\
\hline & & & & ${ }^{238} \mathrm{U}(\mathrm{ppm})$ & 232Th (ppm) & ${ }^{40} \mathrm{~K}(\%)$ & & \\
\hline$\overline{\mathrm{AL1}}$ & active channel & 0.45 & $3.5 \pm 1.5$ & $2.71 \pm 0.05$ & $8.96 \pm 0.10$ & $2.15 \pm 0.01$ & $0.207 \pm 0.021$ & $3.32 \pm 0.21$ \\
\hline AL2 & unit $1\left(T_{2}\right)$ & 0.17 & $3.5 \pm 1.5$ & $3.08 \pm 0.05$ & $10.58 \pm 0.10$ & $2.52 \pm 0.01$ & $0.215 \pm 0.022$ & $3.84 \pm 0.22$ \\
\hline AL3 & unit 2 & 1.00 & $5.0 \pm 2.0$ & $2.93 \pm 0.06$ & $10.30 \pm 0.13$ & $2.42 \pm 0.01$ & $0.209 \pm 0.063$ & $3.64 \pm 0.23$ \\
\hline AL4 & unit 2 & 1.15 & $5.0 \pm 2.0$ & $3.00 \pm 0.07$ & $10.35 \pm 0.15$ & $2.55 \pm 0.01$ & $0.205 \pm 0.061$ & $3.77 \pm 0.23$ \\
\hline AL5 & unit 2 & 2.60 & $5.0 \pm 2.0$ & $2.69 \pm 0.04$ & $9.42 \pm 0.09$ & $2.12 \pm 0.01$ & $0.169 \pm 0.051$ & $3.22 \pm 0.22$ \\
\hline
\end{tabular}

aThe water content is estimated

${ }^{b} \mathrm{~A}$ systematic error of $\pm 8 \%$ is included to the total dose rate (Olley et al., 1996; Murray and Olley, 2002).

nates were used for all samples significantly older than 1000 years (AL3, AL4, AL5), whereas geomagnetic coordinates were used for the younger sediments (AL1 and AL2). As the overburden sediment thickness has not changed significantly for the two latter samples, we attached an error of only $\pm 10 \%$ on the cosmic dose rate. However, the sediment thickness above the erosional unconformity has obviously changed through time, but is difficult to quantify. Hence, we enlarged the error of the cosmic dose rate to $\pm 30 \%$ for the samples underneath the unconformity (AL3, AL4, AL5, unit 2).

Since water attenuates the effect of radiation, a correction for the water content is necessary to determine a realistic dose rate. The correction factor was calculated following Aitken (1985). As the sediment was exposed for five weeks in the trench before sampling - and in the channel for an even longer period of time - the measured water contents of $0.7-1.9 \%$ of the dry weight presumably underestimate the average water content during burial of the sediment. Since water contents of up to $3.4 \%$ were measured in other open outcrops, we assume an average moisture of $3.5 \pm 1.5 \%$ for the younger sediments dated in samples AL1 and AL2. Over longer intervals the moisture was probably higher since the precipitation decreased throughout the Holocene (Markgraf, 1989; García et al., 1999). Therefore, we assume a long-term moisture of $5 \pm 2 \%$ for the three samples from unit 2 (Table 1 ).

\section{Equivalent dose measurements}

Initial tests applying the single aliquot regenerative dose (SAR) protocol of Murray and Wintle (2000) showed slowly decaying signals, suggesting contamination of the quartz sand fraction by feldspar (Fig. 4a). Due to this contamination, we tried to determine equivalent doses $\left(D_{e}\right)$ on potassium-rich feldspar grains by applying the IRSL SAR protocol from Blair et al. (2005) with a preheat and cutheat temperature of $250^{\circ} \mathrm{C}$, an IR stimulation at $50^{\circ} \mathrm{C}$ and a hot bleach of $290^{\circ} \mathrm{C}$. For sample AL1 an anomalous fading rate was calculated according to Huntley and Lamothe (2001) and revealed a high g-value of $\sim 6.5 \%$ /decade based on a delay time of 24 hours $(\mathrm{n}=12)$. This high fading rate would increase the age of the sample by a factor of $\sim 2$, thus a correction for anomalous fading would not result in accurate ages (Huntley and Lamothe, 2001). Stimulation at elevated temperatures by [post-IR] IRSL measurements (Thomsen et al., 2008; Buylaert et al., 2009) significantly reduces the laboratory fading rate, however, the [post-IR] IRSL signal bleaches slowly by sunlight, which increases the probability of acquiring overestimates of burial $\mathrm{D}_{\mathrm{e}}$ owing to partial bleaching (Reimann et al., 2011). Hence, we used only quartz to determine $\mathrm{D}_{\mathrm{e}}$ values, and the measurement sequence for quartz aliquots was improved by inserting an IR bleach of $200 \mathrm{~s}$ at room temperature prior to the detection of the OSL signal (Table 2) (Banerjee et al., 2001; Roberts and Wintle, 2001; Wallinga et al., 2002). The [post-IR] OSL signals indicate much faster decay (Fig. 4c) compared to the one without prior IR stimulation (Fig. 4a), which shows that the IR stimulation successfully removed the OSL signal from feldspar. However, some aliquots still showed a slower decay indicating the existence of an attenuated feldspar signal (Fig. 4b). The OSL signal of sample AL2 was significantly weaker than the signal of the other samples, but it was also dominated by the fast component of the OSL signal (Fig. 4d).

Table 2. The applied [post-IR] OSL protocol of single aliquot regeneration, which is recommended to measure feldspar contaminated samples (Banerjee et al., 2001; Roberts and Wintle, 2001). In the last regeneration cycle the third step is omitted to estimate the IR irradiation. The OSL signal of one regeneration cycle $\left(R_{i}\right)$ derives from dividing the measured signal of a specific given dose $\left(L_{i}\right)$ by the signal from the test dose $\left(T_{i}\right)$.

\begin{tabular}{|c|c|c|}
\hline Step & Treatment & $\begin{array}{l}\text { Observed } \\
\text { signal }\end{array}$ \\
\hline 1 & $\begin{array}{l}\text { Given dose. } D_{i} \text { (beta irradiation using a }{ }^{90} \mathrm{Sr} / 90 \mathrm{Y} \\
\text { source) }\end{array}$ & \\
\hline 2 & Preheat $\left(180^{\circ} \mathrm{C}\right)$ for $10 \mathrm{~s}$ & \\
\hline 3 & IR-bleach (LED, $870 \mathrm{~nm}) @ 0^{\circ} \mathrm{C}$ for $200 \mathrm{~s}$ & \\
\hline 4 & $\begin{array}{l}\text { Stimulation @ } 125^{\circ} \mathrm{C} \text { for } 40 \mathrm{~s} \text { using blue LED } \\
(470 \mathrm{~nm}) \text { and parallel detection of the post IR } \\
\text { quartz signal (Hoya U-340 filter) }\end{array}$ & $\mathrm{Li}_{\mathrm{i}}$ \\
\hline 5 & Given test dose $D_{t}$ & \\
\hline 6 & Cutheat $\left(160^{\circ} \mathrm{C}\right)$ for $10 \mathrm{~s}$ & \\
\hline 7 & IR-bleach @ $0^{\circ} \mathrm{C}$ for $200 \mathrm{~s}$ & \\
\hline 8 & Stimulation @ $125^{\circ} \mathrm{C}$ for $40 \mathrm{~s}$ (blue LED) & $\mathrm{T}_{\mathrm{i}}$ \\
\hline 9 & Return to step 1 & \\
\hline
\end{tabular}



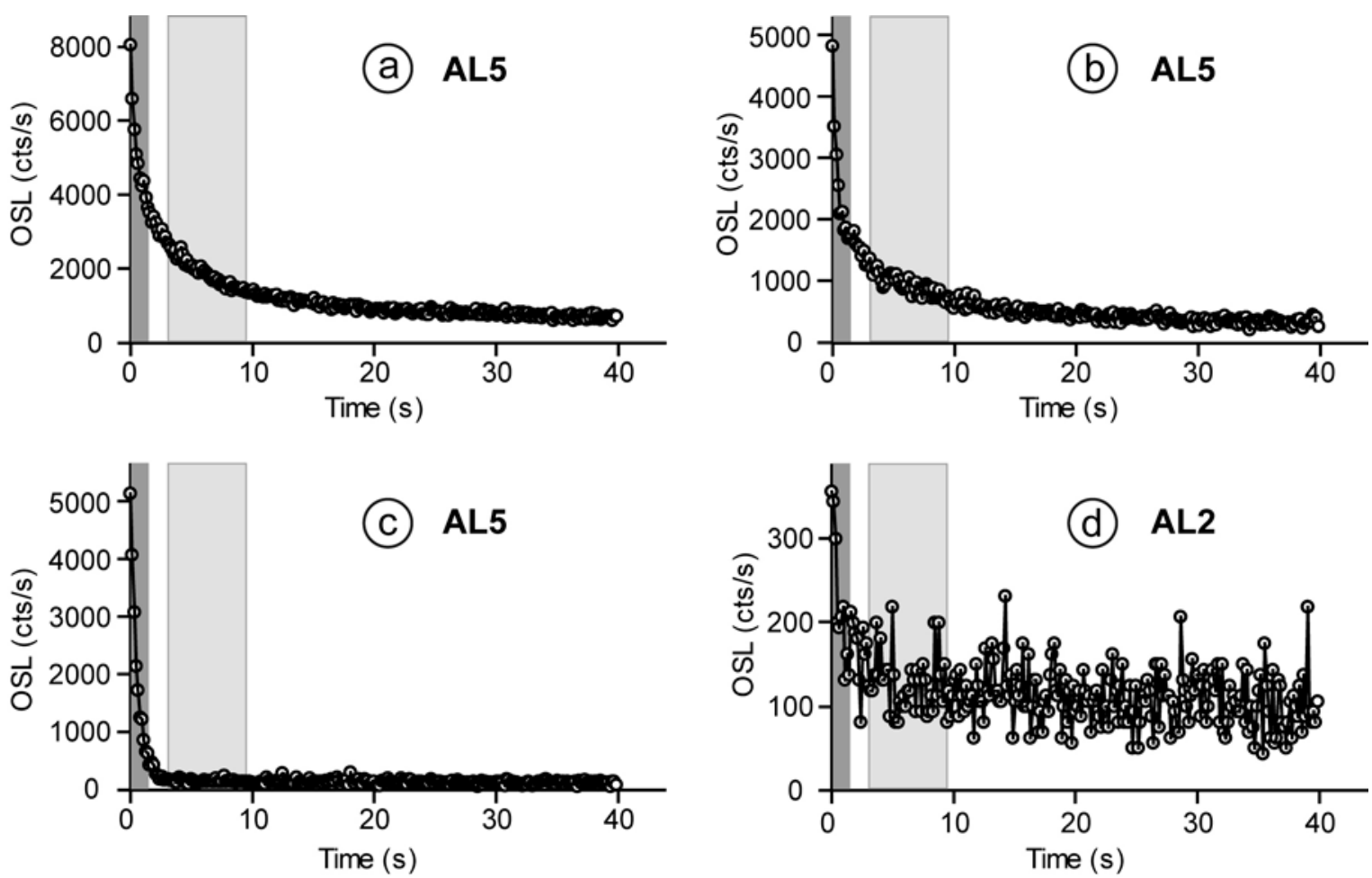

Fig. 4. Comparison of different shapes of quartz OSL decay curve signals after HF etching. The dark gray field indicates the signal integration limit, whereas the light gray field shows the subtracted background interval of the signal. (a) The quartz signal is affected by feldspar impurities as indicated by the slowly decreasing decay curve. (b) OSL signal of quartz after IR bleaching for 200 s. Some aliquots still show slow decay, but significantly less than without previous IR bleaching. (c) Clean quartz signal after IR bleaching for $200 \mathrm{~s}$. (d) Very weak natural signal of sample AL2.

To generate the dose-response curve using the SAR protocol in Table 2, the natural signal of the aliquots $(\mathrm{N})$ was measured in the first cycle, followed by six regeneration cycles. The first three regeneration cycles (R1-R3) were used to bracket the natural luminescence level; the fourth cycle (R4) was measured without given dose to monitor the recuperation (i.e. R4/N). In the fifth cycle (R5) the reproducibility of the regenerated signal was monitored, since the given dose was equal to R2. The recycling ratio was calculated by dividing $\mathrm{R} 5$ by $\mathrm{R} 2$. The sixth cycle (R6) was measured without IR stimulation to estimate the influence of feldspar contamination (R6/R5) (Duller, 2003).

Prior to the determination of the $\mathrm{D}_{\mathrm{e}}$ values, dose recovery tests (Roberts et al., 1999; Murray and Wintle, 2003) were applied on the samples AL2 and AL5 to test different preheat temperatures in combination with a cutheat temperature at $160^{\circ} \mathrm{C}$. Apart from the variable preheat temperature, the sequence was identical to the one presented in Table 2. For $\mathrm{D}_{\mathrm{e}}$ value determination a saturating exponential function was applied to fit the dose response curves. Both tested samples yielded their best results on dose recovery and recycling ratio for a preheat temperature of $180^{\circ} \mathrm{C}$ (Fig. 5), and the recuperation was below $5 \%$ for all tested temperatures. Furthermore, the best dose recovery ratio was obtained for a signal integrating over the first $1.6 \mathrm{~s}$ of stimulation, combined with a subtraction of an early background interval from 3.2 to $9.6 \mathrm{~s}$. This extracts the signal dominated by the fast component (e.g. Cunningham and Wallinga, 2010) and these signal and background intervals were consequently applied to all samples (Fig. 4).

The required amount of aliquots to obtain a reliable burial $D_{e}$ depends largely on the scattering of single $D_{e}$ measurements. Rodnight (2008) suggested to use a minimum of $50 \mathrm{D}_{\mathrm{e}}$ values in partially bleached samples. We measured until at least 70 aliquots were available (Table 3 ) after applying the following rejection criteria: aliquots which showed (i) a recuperation of more than $5 \%$ of the natural signal, (ii) recycling ratios with nominal values of more than $\pm 15 \%$ (due to the dim signal we did not use $\pm 10 \%$; Fig. 5), and (iii) aliquots with a slow decay curve due to feldspar contamination, or the dominance of slow components from quartz (Madsen et al., 2009), were rejected. After applying these rejection criteria, the feldspar contamination was assessed by analyzing the IROSL depletion ratio (Duller, 2003). In samples AL3 and AL4 the ratio is significantly higher than in the other samples (Fig. 6). Sample AL3 (Fig. 6c), as well as the less contaminated samples AL1, AL2 and AL5 (Fig. 6a, b, d), indicate no correlation between $D_{e}$ values and IROSL depletion ratios. This suggests that the IR bleach prior to the OSL measurement successfully removed the feldspar OSL signal and that the aliquots contaminated 

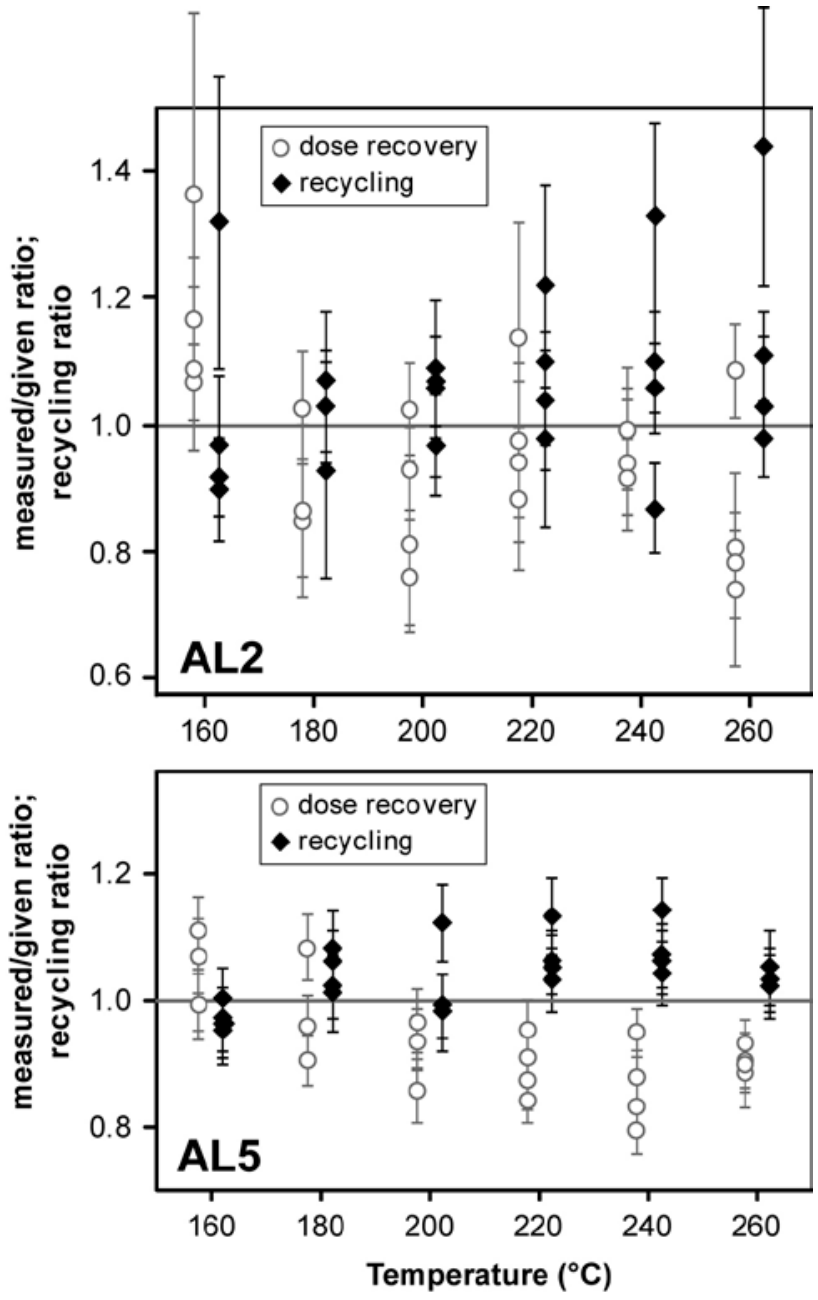

Fig. 5. Results from the dose recovery and recycling on medium sized aliquots for samples AL2 and AL5. The cutheat temperature was set to $160^{\circ} \mathrm{C}$. The preheat temperature of $180^{\circ} \mathrm{C}$ yielded the best dose recovery and recycling ratios in both samples. with feldspar did not have any systematic effect on the $\mathrm{D}_{\mathrm{e}}$ values. Only sample AL4 shows a weak negative correlation for very high IR-OSL depletion ratio values (Fig. 6e). All aliquots shown in Fig. 6 were used for statistical analyses of the $\mathrm{D}_{\mathrm{e}}$ values to obtain the ages.

\section{ANALYSES OF EQUIVALENT DOSE DISTRI- BUTIONS AND STATISTICAL TREATMENT}

The $\mathrm{D}_{\mathrm{e}}$ values and OSL ages are summarized in Table 3 and visualized by probability density curves and radial plots in Fig. 7. All dose distributions show a considerable scatter (high relative standard deviation, RSD) and have a clear asymmetry with significant positive skewness (Table 3, Fig. 7). Both high RSD and skewness are clear indicators of incomplete bleaching (Wallinga, 2002; Bailey and Arnold, 2006) or differences in microdosimetry due to sediment heterogeneity (Murray and Roberts, 1997; Vandenberghe et al., 2003). The sample from the deepest incised channel in the study area (AL1) indicates a broad scatter with a RSD of $28 \%$ (Table 3; Fig. 7a). The distribution is similar to type 3 of the Colorado arroyo samples presented by Arnold et al. (2007) who concluded that probably other sources than heterogeneous bleaching are also important, e.g. differences in microdosimetry or post-depositional mixing. In sample AL2 from unit 1 the measured aliquots show a broad range of $D_{e}$ values over more than one order of magnitude (1.3 to 55 Gy; Fig. 7b), which is also indicated by the high RSD value of $46 \%$ (Table 3 ). The three samples from unit 2 (AL3, AL4 and AL5) indicate different $\mathrm{D}_{\mathrm{e}}$ distributions. The distribution of sample AL3 is similar to type 1 of Arnold et al. (2007). It has a clear peak at $\sim 40 \mathrm{~Gy}$ and the significant positive skewness of 1.02 is most probably related to heterogeneous bleaching. In contrast, samples AL4 and AL5 show $\mathrm{D}_{\mathrm{e}}$ distributions with a broader range of frequent $D_{e}$ values including minor peaks.

The ages were calculated using the minimum age model with three components (MAM3) and the central age model (CAM). The CAM determines the weighted mean but also accounts for additional dispersion resulting

Table 3. $D_{e}$ values and OSL ages by using different statistical approaches. In all samples the 100 to $150 \mu m$ size fraction was measured on aliquots composed of $\sim 50$ grains. The measurement error is assumed to be $2 \%$. All errors are given as $1 \sigma$ uncertainties.

\begin{tabular}{|c|c|c|c|c|c|c|c|c|c|}
\hline $\begin{array}{l}\text { sample } \\
\text { ID }\end{array}$ & $\begin{array}{c}\text { No. of } \\
\text { aliqouts a) }\end{array}$ & $\begin{array}{c}\text { RSD }^{\text {b) }} \\
(\%)\end{array}$ & skewness & $\begin{array}{c}D_{\text {e }} \text { MAM c) } \\
\sigma_{O D}=0.1(G y)\end{array}$ & $\begin{array}{c}\left.D_{\mathrm{e}} \text { MAM } \mathrm{c}\right) \\
\sigma_{O D}=0.2(\mathrm{~Gy})\end{array}$ & $\begin{array}{c}D_{e} \text { CAM d) } \\
(G y)\end{array}$ & $\begin{array}{l}\text { age MAM c) } \\
\sigma O D=0.1(\mathrm{ka})\end{array}$ & $\begin{array}{l}\text { age MAM c) } \\
\sigma_{O D}=0.2(\mathrm{ka})\end{array}$ & $\begin{array}{l}\text { age CAM d) } \\
\text { (ka) }\end{array}$ \\
\hline $\mathrm{AL1}$ & $74(92)$ & 28 & $0.51 \pm 0.28$ & $43.4 \pm 2.1$ & $50.5 \pm 3.8$ & $64.1 \pm 2.1$ & $13.1 \pm 1.0$ & $15.2 \pm 1.5$ & $19.3 \pm 1.4$ \\
\hline AL2 & 102 (158) & 46 & $1.14 \pm 0.24$ & $2.37 \pm 0.18$ & $3.04 \pm 0.21$ & $5.92 \pm 0.33$ & $0.616 \pm 0.059$ & $0.770 \pm 0.076$ & $1.54 \pm 0.12$ \\
\hline AL3 & $84(112)$ & 32 & $1.02 \pm 0.27$ & $36.8 \pm 2.0$ & $44.6 \pm 3.2$ & $51.8 \pm 1.6$ & $10.13 \pm 0.85$ & $12.3 \pm 1.2$ & $14.2 \pm 1.0$ \\
\hline AL4 & $74(96)$ & 31 & $1.29 \pm 0.28$ & $39.0 \pm 1.9$ & $46.2 \pm 3.4$ & $60.0 \pm 2.7$ & $10.34 \pm 0.81$ & $12.3 \pm 1.2$ & $15.9 \pm 1.1$ \\
\hline AL5 & $114(140)$ & 33 & $0.65 \pm 0.23$ & $30.4 \pm 1.5$ & $37.6 \pm 2.3$ & $51.9 \pm 1.8$ & $9.44 \pm 0.80$ & $11.7 \pm 1.1$ & $16.1 \pm 1.2$ \\
\hline
\end{tabular}

aThe number of accepted aliquots is given in front of the brackets, while the total number of aliquots measured in each sample is given in parentheses.

${ }^{b} R S D=$ relative standard deviation

${ }^{c} M A M=$ minimum age model; $\sigma_{O D}=$ overdispersion value

${ }^{d} \mathrm{CAM}=$ central age model 

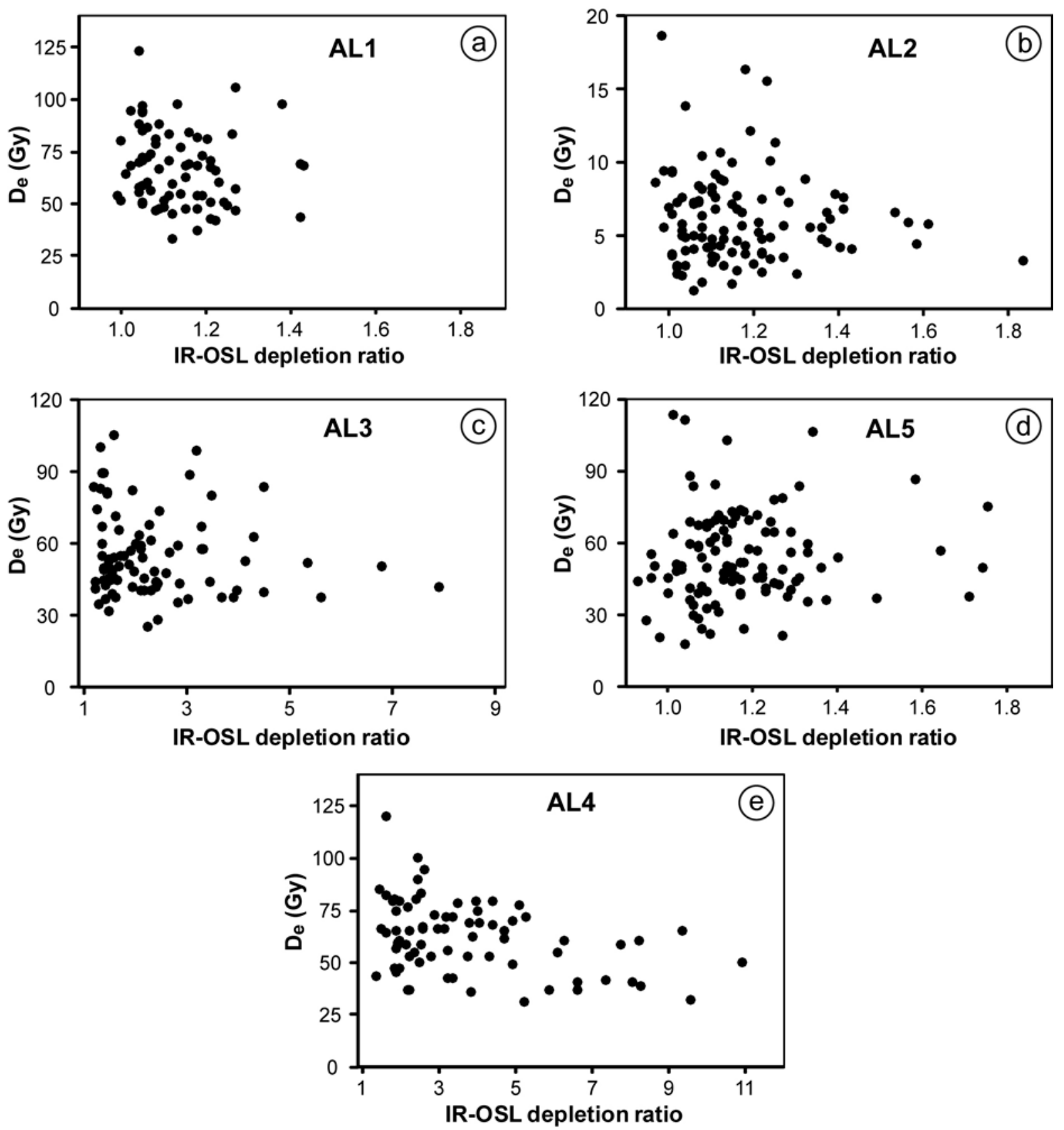

Fig. 6. IR-OSL depletion ratios (R6/R5) plotted against the $D_{e}$ values of each aliquot. (a-d) No trend is visible, which suggests that the feldspar has no direct influence on the equivalent dose of the quartz aliquots. (e) Only the strongest contaminated sample (AL4) shows a weak negative correlation between feldspar content and equivalent dose for high IR signals. Note the different scale of the axes.

from measurement uncertainties (Galbraith et al., 1999). The MAM identifies the well-bleached aliquots by fitting a truncated normal distribution to the $\log \mathrm{D}_{\mathrm{e}}$ values (Galbraith and Laslett, 1993; Galbraith et al., 1999). The breadth of this minimum $D_{e}$ population is derived from statistical measurement errors of each $\mathrm{D}_{\mathrm{e}}$ value and the overdispersion $\left(\sigma_{\mathrm{OD}}\right)$ which is a sediment-specific spread of the well-bleached population. Published overdispersion values for multi-grain $\mathrm{D}_{\mathrm{e}}$ distributions range from $0 \%$ to $35 \%$ with the majority lying between $10 \%$ and
20\% (e.g. Galbraith et al., 2005; Jacobs et al., 2006; Jacobs et al., 2008; Arnold and Roberts, 2009). The large variation in overdispersion values is caused by differences in the regional and sedimentary settings, microdosimetry variations, and factors related to the measurement procedure, e.g. measurement protocol, curve fitting, and rejection criteria (Galbraith et al., 2005; Jacobs et al., 2008). As we do not know the specific overdispersion value for our samples, we applied the MAM with two different values of 10 and $20 \%$, respectively. 
(a)

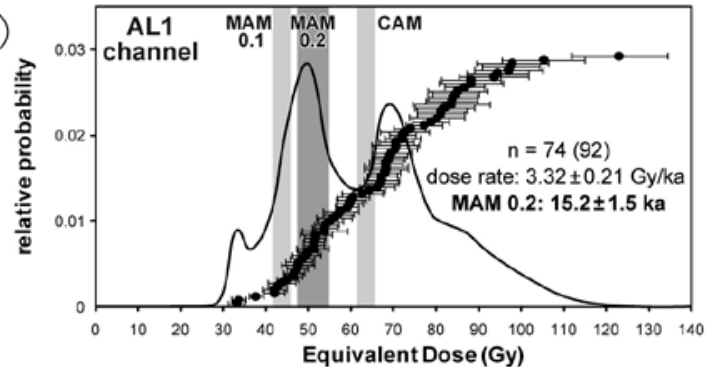

(b)



(c)

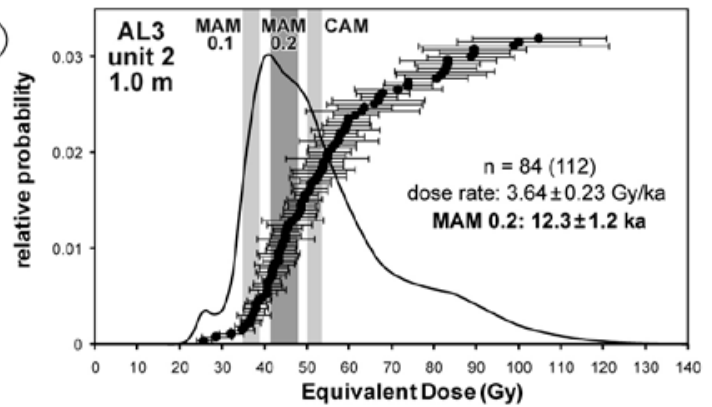

(d)

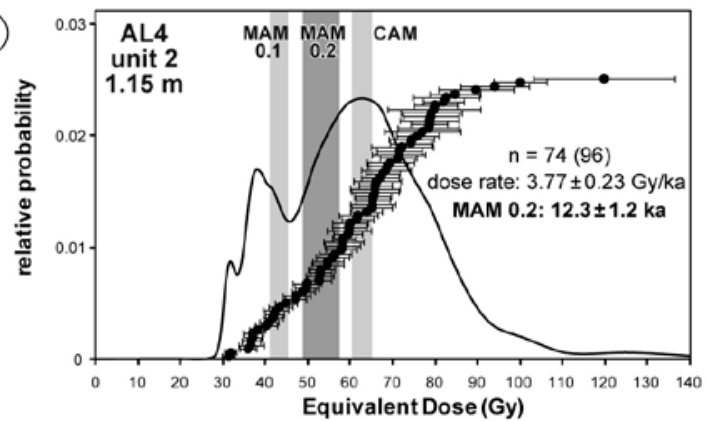

(e)

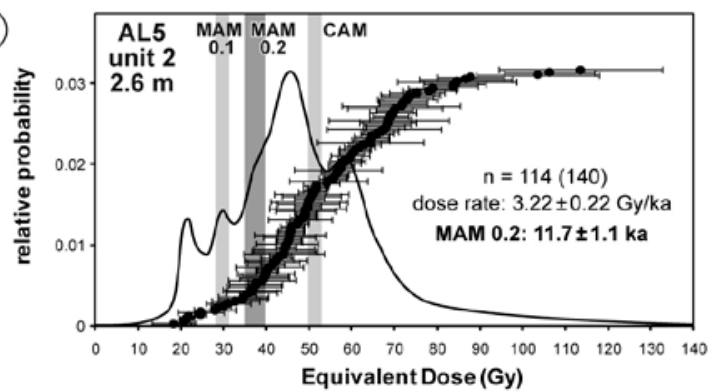

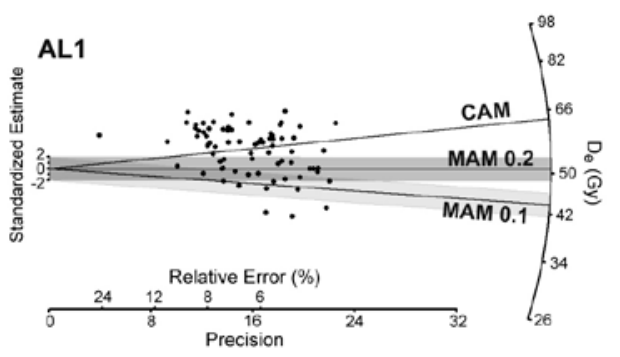
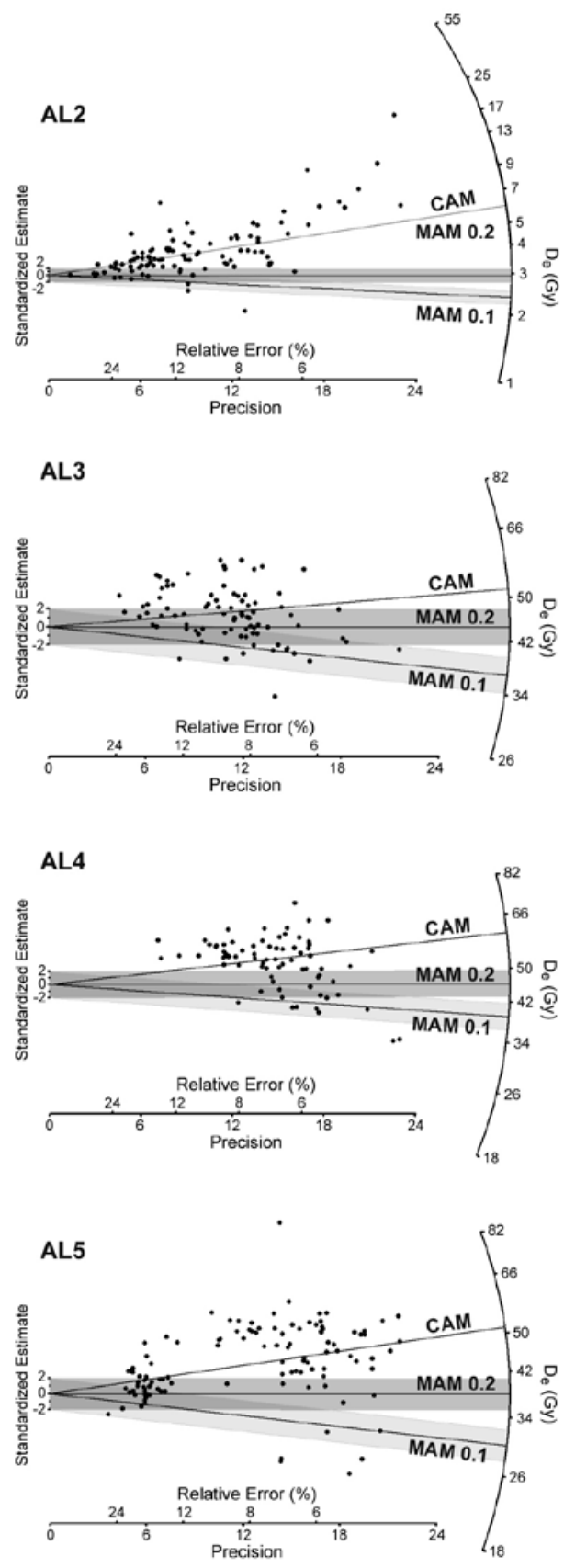

Fig. 7. Probability density curves and radial plots of the OSL samples. For better overview five outlying aliquots $\left(D_{\theta}>140\right.$ Gy in $A L 1$ and AL5; $D_{\mathrm{e}}>20 \mathrm{~Gy}$ in AL2) are not shown in the probability density curves although they are included in the statistics. Except of sample AL1, all ages are consistent with stratigraphy (compare to Fig. 3a). Note the different interval of equivalent doses for sample AL2. $D_{\mathrm{e}}$ values obtained from the different age models are indicated within their $1 \sigma$ error in the probability density plots and their $2 \sigma$ error in the radial plots. MAM 0.1: minimum age model with overdispersion of 10\%. MAM 0.2: minimum age model with overdispersion of 20\%. CAM: central age model. 
In all samples the MAM with an overdispersion of $10 \%$ yielded the smallest $\mathrm{D}_{\mathrm{e}}$ value, the CAM the largest and the MAM with $20 \%$ overdispersion an intermediate value (Table 3; Fig. 7). The ages obtained by the MAMs using different overdispersion values are statistically consistent within $2 \sigma$ errors and in three samples they also agree within $1 \sigma$ errors. The sample from the deepest incised channel (AL1) is apparently the oldest one with a minimum age of $13.1 \pm 1.0 \mathrm{ka}$ using $10 \%$ overdispersion and $15.2 \pm 1.5 \mathrm{ka}$ using $20 \%$ overdispersion (Table 3 ). The age obtained from the CAM is $19.3 \pm 1.4 \mathrm{ka}$. Sample AL2 from unit 1 has a minimum age of $616 \pm 59$ years $(10 \%$ overdispersion), and $770 \pm 76$ years ( $20 \%$ overdispersion), whereas the central age is $1.54 \pm 0.12 \mathrm{ka}$. The three samples from unit 2 yielded ages of $12.3 \pm 1.2 \mathrm{ka}, 12.3 \pm 1.2 \mathrm{ka}$ and $11.7 \pm 1.1 \mathrm{ka}$ using the MAM with $20 \%$ overdispersion. For both other age models - the MAM with $10 \%$ overdispersion and the CAM - all three ages from unit 2 appear to be either $\sim 2$ ka younger or 2-4 ka older with respect to the MAM with $20 \%$ overdispersion (Table 3).

\section{RADIOCARBON DATING}

For radiocarbon dating three plant remnants were collected from unit 1 (Fig. 3). They had a significant darker brown color than recent plants and did not comprise elastic components. Nevertheless it was not possible to evaluate whether the plant remnants were transported in one of the debris flows related to the deposition of unit 1 , or if they derived from shrubs or cactuses that have grown on terrace $T_{2}$ after its formation. Sample preparation and accelerator mass spectrometry (AMS) measurements were undertaken at the Center for Applied Isotope Studies, University of Georgia (USA). The uncalibrated radiocarbon ages range from $\sim 135$ to $\sim 200$ years BP (Table 4) and yield calibrated age ranges of 1655-1951, 1692-1952 and 1687-1953 AD ( $\sigma \sigma$ errors, Table 4), thus all three samples are younger than $\sim 350$ years.

\section{DISCUSSION}

In this study we present radiocarbon and OSL ages from different units of alluvial deposits at the mountain front of the Andean Precordillera near Mendoza. The OSL age for the upper unit 1 in the trench is significantly older than the respective radiocarbon ages. While all radiocarbon ages are very young (i.e. 1655-1953 AD,
Table 4), even the younger minimum OSL age for this unit (AL2) is $616 \pm 118$ years ( $2 \sigma$ error, $10 \%$ overdispersion), i.e. 1277-1513 AD. The following arguments suggest that the radiocarbon ages underestimate the depositional age of unit 1: (i) The moderately developed desert pavement that covers terrace $T_{2}$ suggests an exposure history longer than $\sim 350$ years, and (ii) terrace $T_{2}$ has been tectonically offset by three earthquakes (Salomon, 2010), which did not all occur within the past $\sim 350$ years as indicated by the historical record. The most likely explanation for the young radiocarbon ages is that the dated samples derive from plants that grew on terrace $T_{2}$ after its formation, which fits to the abundant shrubs and cactuses that grow nowadays on the terraces and whose roots reach depths of at least $2.5 \mathrm{~m}$ as observed in the trench walls. Hence, we conclude that the radiocarbon ages provide only a minimum age constraint.

Stratigraphically consistent OSL ages from units 1 and 2 are bracketed between ages derived from the central age model (CAM) and the minimum age model (MAM) with an assumed overdispersion of $10 \%$. The selection criteria of Arnold et al. (2007) suggest that the ages from the MAM are more reliable than the ages from the CAM due to the significant skewness of the $D_{e}$ distribution in all measured samples (Table 3). The MAM with a low overdispersion of $10 \%$ is quite sensitive to outliers with low $\mathrm{D}_{\mathrm{e}}$ values, which may result in an underestimation of the inferred burial age. This accounts especially for samples AL2 and AL5 as they only contain very few aliquots inside the range of the MAM with $10 \%$ overdispersion (Fig. 7b, e). Recently, Arnold and Roberts (2009) summarized all published overdispersion values and obtained a mean value of $20 \pm 9 \%$ for single grains and $14 \pm 7 \%$ for small aliquots. Studies providing overdispersion values from small aliquots of fluvial and alluvial sediments yielded a mean overdispersion value of $19 \pm 7 \%$ (Feathers et al., 2006; Arnold et al., 2007). Hence, we assume that a value of $20 \%$ overdispersion is more appropriate for our samples and we regard the ages from the MAM with $20 \%$ overdispersion as our best age estimates. Thus, unit 1 most likely has a depositional age of $770 \pm 76$ years ( $1 \sigma$ error, Table 3 ). Unfortunately, no accurate independent age control is available because the radiocarbon samples yielded only minimum ages. Furthermore, the exposed terrace sediments are too young to apply exposure dating, as the concentration of cosmogenic nuclides is too low to be measured with high precision.

Table 4. Results of radiocarbon dating in unit 1 of the trench. All samples were derived from plant remnants. See discussion for age interpretation.

\begin{tabular}{ccccccc}
\hline field ID & lab ID \#UGAMS & depth below surface $(\mathbf{c m})$ & $\delta^{13} \mathbf{C}(\%)$ & ${ }^{14} \mathbf{C}$ age $(\mathbf{1} \sigma)(\mathrm{BP})$ & cal BP $(\mathbf{2 \sigma})^{\text {a }}$ & cal AD $(\mathbf{2} \sigma)$ \\
\hline AC23 & 5100 & 45 & $-21,6$ & $200 \pm 25$ & $-1-295$ & $1655-1951$ \\
AC28 & 5102 & 60 & $-20,4$ & $135 \pm 25$ & $-2-258$ & $1692-1952$ \\
AC32 & 5104 & 55 & $-24,0$ & $145 \pm 25$ & $-2-263$ & $1687-1953$ \\
\hline
\end{tabular}

aCalibrated by using CALIB 6.0 (Stuiver and Reimer, 2011) and the SHCal04 calibration curve (McCormac et al., 2004).

UGAMS = University of Georgia Accelerated Mass Spectrometry 
And uranium series dating is not feasible, because the carbonate coatings on clasts are scarce and very thin where they occur. The samples of unit 2 are distributed over a sediment thickness of one meter (Fig. 3) and yielded ages of $12.3 \pm 1.2 \mathrm{ka}, 12.3 \pm 1.2 \mathrm{ka}$ and $11.7 \pm 1.1 \mathrm{ka}$ by applying the MAM with $20 \%$ overdispersion. Hence, unit 2 was most likely deposited between $\sim 10$ and $\sim 14$ ka. This age interval is similar to the age of 11-13 ka that was obtained by ${ }^{10} \mathrm{Be}$ and ${ }^{14} \mathrm{C}$ dating of an alluvial terrace $30 \mathrm{~km}$ north of the study area (Schmidt et al., 2011a). Three alluvial surfaces near San Juan $(150 \mathrm{~km}$ north of the study area) yielded also latest Pleistocene and Holocene ages by ${ }^{10} \mathrm{Be}$ dating (Siame et al., 2002).

In general, the formation of alluvial terraces is caused by the incision of rivers - a process that is mainly controlled by variations in climate (e.g. Hancock and Anderson, 2002; Hetzel et al., 2006). The sediments from terrace $T_{2}$ (unit 1) and its underlying deposits (unit 2) reveal a pronounced change in sedimentary facies and the OSL ages for these deposits may reflect changes in climate. The carbonate-rich silt layers in unit 2 (Fig. 3) were presumably deposited in a floodplain environment when the margin of the alluvial fan was still located farther west than today. This interpretation is supported by the presence of lacustrine sediments in the Borbollón and Capdeville anticlines to the east of the study area, which are intercalated with tuff layers that were dated at $16.6 \pm 0.6 \mathrm{ka}$ and $27.9 \pm 0.6 \mathrm{ka}$ by ${ }^{40} \mathrm{Ar} /{ }^{39} \mathrm{Ar}$ in biotite (Olgiati and Ramos, 2003) (Fig. 1b). The sandy layers with minor clasts in unit 2 (Fig. 3) are interpreted as distal alluvial fan deposits. The frequent alternation between calcite-rich silt layers and sandy layers exposed in unit 2 indicates that alluvial sedimentation gradually propagated onto the floodplain $\sim 12 \mathrm{ka}$ ago, which coincides with a period of increased humidity and melting glaciers in the region (D'Antonio, 1983; Markgraf, 1989; García et al., 1999). After $\sim 10 \mathrm{ka}$, when the climate shifted to warmer and drier conditions (D'Antonio, 1983; García et al., 1999), the alluvial fan propagated towards the east and the floodplain sedimentation ended at the trench site. If this interpretation is correct, the main surface of the present-day alluvial fan $\left(\mathrm{T}_{4}\right)$, which had probably covered the whole study area, must be somewhat younger than the floodplain sediments of unit 2 . Changes in climate, specifically the increased aridity during the Holocene, led to progressive incision of the alluvial fan and the formation of lower terrace levels. One of them is the $770 \pm 76$ years old terrace $T_{2}$, which formed during rapid deposition of unit 1 and subsequent incision. As a result, unit 1 overlies the older sediments of unit 2 along a prominent unconformity. Both units were affected by three earthquakes on the Cal thrust fault as indicated by the three folds in unit 1 and related colluvial wedges (Fig. 3). The latest of these events was presumably the 1861 earthquake (Salomon, 2010). The lower unit 2 has experienced at least two older events between $\sim 12 \mathrm{ka}$ and $\sim 0.8 \mathrm{ka}$, as indicated by fold structures in unit 2 and the two colluvial wedges underneath the unconformity.

Terrace $T_{1}$ is younger than $\sim 800$ years since it was deposited after the formation of terrace $T_{2}$. A fault scarp on terrace $T_{1}$ north of the trench indicates that this terrace was affected by the earthquake in 1861 (Schmidt et al., $2011 \mathrm{~b}$ ). Hence, the age of terrace $T_{1}$ is bracketed between $\sim 800$ and 150 years. The still active surface $\mathrm{T}_{0}$ is interpreted to postdate the last earthquake ( $\leq 150$ years) since it is not offset by the fault. To the west of the study area, a large artificial channel was built in 1969 (Fig. 2) in order to protect Mendoza from debris flows and sheet floods moving down the alluvial fan. Hence, the sediment underneath surface $T_{0}$ was deposited before 1969, but after the last earthquake in 1861. However, the OSL sample AL1, which was taken from the deepest incised channel, yielded an age of $15.2 \pm 1.5 \mathrm{ka}$ (MAM with $20 \%$ overdispersion; Table 3), i.e. much older than expected. In contrast to unit 2 , the material of sample AL1 comes from an unconsolidated sand lens, arguing against a $\sim 15$ ka old deposit that was exposed during incision of the channel. Even the smallest $D_{e}$ value obtained from AL1 has $33 \mathrm{~Gy}$, which is equivalent to $\sim 10 \mathrm{ka}$ of burial. The most likely explanation for the old apparent age is a reworking of relatively old sedimentary deposits upstream and a transport without any exposure to sunlight. We assume that the transport probably occurred by a debris flow during night. The results from sample AL1 illustrate that alluvial sediments are not always datable by OSL techniques, because the basic assumption of bleaching during transport may fail completely.

\section{CONCLUSIONS}

Numerical dating of alluvial deposits provides key to understanding sedimentary processes and tectonic activity in many areas of the world. The dating methods to be applied have to be chosen carefully and the reliability of the obtained ages should be critically discussed in the context of their respective geological setting (e.g. sample AL1). With respect to radiocarbon dating, our results show that caution is needed when sampling plant remnants in layers that are penetrated by recent roots. In this study we obtained four consistent OSL ages from alluvial deposits at the front of the Andean Precordillera by applying the [post-IR] OSL measurement sequence on quartz. The IR-OSL stimulation successfully removed the feldspar OSL signal from the quartz aliquots, so that the feldspar contamination does not have a systematic effect on the dose estimate. Thus, rejection of contaminated aliquots based on the IR-depletion ratio was not necessary in our samples.

In the investigated trench, the two distinct sedimentary units yielded stratigraphically consistent ages, with the minimum and central age models representing reasonable lower and upper bounds for the burial ages. The MAM with an overdispersion of $20 \%$ yields the most 
likely burial ages. The studied deposits in the trench record a change in sedimentary facies from floodplain to alluvial sedimentation in the latest Pleistocene. During the Holocene the alluvial fan sediments were incised by high-energy debris flows, which led to the formation of a series of inset terraces. Our study illustrates that OSL dating of alluvial fan sediments can be applied successfully if appropriate procedures are used. These include the preparation of aliquots with only a few light-emitting grains, the measurement of a statistical relevant amount of aliquots, and the application of an adequate age model.

\section{ACKNOWLEDGEMENTS}

We thank Francisco Mingorance for the organization of the trench excavation and Jörg Giese and Tony Reimann for copious discussions and the corrections of an earlier version of this manuscript. Furthermore, we thank two anonymous reviewers for their thorough and constructive comments which helped us to improve the manuscript, and Grzegorz Adamiec for the editorial handling. Funding by the German Research Foundation (DFG; grant no. HE 1704/6-1) is gratefully acknowledged.

\section{REFERENCES}

Adamiec G and Aitken M, 1998. Dose-rate conversion factors: update. Ancient TL 16(2): 37-50.

Aitken MJ, 1985. Thermoluminescence Dating. Academic Press, New York: $351 \mathrm{pp}$.

Alappat L, Vink A, Tsukamoto S and Frechen M, 2010. Establishing the Late Pleistocene-Holocene sedimentation boundary in the southern North Sea using OSL dating of shallow continental shelf sediments. Proceedings of the Geologists' Association 121(1): 43-54, DOI 10.1016/j.pgeola.2009.12.006.

Anders MD, Pederson JL, Rittenour TM, Sharp WD, Gosse JC, Karlstrom KE, Crossey LJ, Goble RJ, Stockli L and Yang GA, 2005. Pleistocene geomorphology and geochronology of eastern Grand Canyon: linkages of landscape components during climate changes. Quaternary Science Reviews 24(23-24): 2428-2448, DOI 10.1016/j.quascirev.2005.03.015.

Arnold LJ and Roberts RG, 2009. Stochastic modelling of multi-grain equivalent dose $\left(\mathrm{D}_{\mathrm{e}}\right)$ distributions: Implications for OSL dating of sediment mixtures. Quaternary Geochronology 4(3): 204-230, DOI 10.1016/j.quageo.2008.12.001.

Arnold LJ, Bailey RM and Tucker, GE, 2007. Statistical treatment of fluvial dose distributions from southern Colorado arroyo deposits. Quaternary Geochronology 2(1-4): 162-167, DOI 10.1016/j.quageo.2006.05.003.

Askew BL and Algermissen ST, 1985. Catalog of Earthquakes for South America: Hypocenter and Intensity Data. Volumes 4, 6, 7ac, CERESIS, Lima.

Bailey RM and Arnold LJ, 2006. Statistical modelling of single grain quartz $\mathrm{D}_{\mathrm{e}}$ distributions and an assessment of procedures for estimating burial dose. Quaternary Science Reviews 25(19-20): 24752502, DOI 10.1016/j.quascirev.2005.09.012.

Banerjee D, Murray AS, Bøtter-Jensen L and Lang A, 2001. Equivalent dose estimation using a single aliquot of polymineral fine grains. Radiation Measurements 33(1): 73-94, DOI 10.1016/S13504487(00)00101-3.

Blair MW, Yukihara EG and McKeever SWS, 2005. Experiences with single-aliquot OSL procedures using coarse-grain feldspars. $R a$ - diation Measurements 39(4): 361-374, DOI 10.1016/j.radmeas.2004.05.008.

Bøtter-Jensen L, Andersen CE, Duller GAT and Murray AS, 2003. Developments in radiation, stimulation and observation facilities in luminescence measurements. Radiation Measurements 37(4-5): 535-541, DOI 10.1016/S1350-4487(03)00020-9.

Buylaert JP, Murray AS, Thomsen KJ and Jain M, 2009. Testing the potential of an elevated temperature IRSL signal from K-feldspar. Radiation Measurements 44(5-6): 560-565, DOI 10.1016/j.radmeas.2009.02.007.

Cunningham AC and Wallinga J, 2010. Selection of integration time intervals for quartz OSL decay curves. Quaternary Geochronology 5(6): 657-666, DOI 10.1016/j.quageo.2010.08.004.

Cupper ML, 2006. Luminescence and radiocarbon chronologies of playa sedimentation in the Murray Basin, southeastern Australia. Quaternary Science Reviews 25(19-20): 2594-2607, DOI 10.1016/j.quascirev.2005.09.011.

D'Antonio H, 1983. Pollen analysis of Gruta del Indio. Quaternary of South America and Antarctic Peninsula 1: 83-104.

DeLong SB and Arnold LJ, 2007. Dating alluvial deposits with optically stimulated luminescence, AMS ${ }^{14} \mathrm{C}$ and cosmogenic techniques, western Transverse Ranges, California, USA. Quaternary Geochronology 2(1-4): 129-136, DOI 10.1016/j.quageo.2006.03.012.

Duller GAT, 2003. Distinguishing quartz and feldspar in single grain luminescence measurements. Radiation Measurements 37(2): 161165, DOI 10.1016/s1350-4487(02)00170-1.

Fattahi M, Walker R, Hollingsworth J, Bahroudi A, Nazari H, Talebian M, Armitage S and Stokes S, 2006. Holocene slip-rate on the Sabzevar thrust fault, NE Iran, determined using optically stimulated luminescence (OSL). Earth and Planetary Science Letters 245(34): 673-684, DOI 10.1016/j.epsl.2006.03.027.

Feathers JK, Holliday VT and Meltzer DJ, 2006. Optically stimulated luminescence dating of Southern High Plains archaeological sites. Journal of Archaeological Science 33(12): 1651-1665, DOI 10.1016/j.jas.2006.02.013.

Folguera A, Etcheverría M, Pazos PJ, Giambiagi L, Fauqué L, Cortés JM, Rodríguez MF, Irigoyen MV and Fusari C, 2003. Hoja Geológica 3369-15, Potrerillos. Provincia de Mendoza (Geological Map 3369-15, Potrerillos. Mendoza province). Instituto de Geología y Recursos Minerales, Servicio Geológico Minero Argentino. Boletín 301, Buenos Aires: 144pp (in Spanish).

Folz E, Bodu P, Bonte P, Joron JL, Mercier N and Reyss JL, 2001. OSL dating of fluvial quartz from Le Closeau, a Late Paleolithic site near Paris - comparison with C-14 chronology. Quaternary Science Reviews 20(5-9): 927-933, DOI 10.1016/S02773791(00)00062-7.

Galbraith RF and Green PF, 1990. Estimating the component ages in a finite mixture. Nuclear Tracks and Radiation Measurements 17(3): 197-206, DOI 10.1016/1359-0189(90)90035-V.

Galbraith RF and Laslett GM, 1993. Statistical models for mixed fission track ages. Nuclear Tracks and Radiation Measurements 21(4): 459-470, DOI 10.1016/1359-0189(93)90185-C.

Galbraith RF, Roberts RG, Laslett GM, Yoshida H and Olley JM, 1999. Optical dating of single and multiple grains of quartz from Jinmium rock shelter, northern Australia: part 1. Experimental design and statistical models. Archaeometry 41(2): 339-364, DOI 10.1111/j.1475-4754.1999.tb00987.x.

Galbraith RF, Roberts RG and Yoshida H, 2005. Error variation in OSL palaeodose estimates from single aliquots of quartz: a factorial experiment. Radiation Measurements 39(3): 289-307, DOI 10.1016/j.radmeas.2004.03.023.

García A, Zárate M and Paez MM, 1999. The Pleistocene/Holocene transition and human occupation in the Central Andes of Argentina: Agua de la Cueva locality. Quaternary International 53-54: 43-52, DOI 10.1016/S1040-6182(98)00006-8.

Hancock GS and Anderson RS, 2002. Numerical modeling of fluvial strath-terrace formation in response to oscillating climate. Geological Society of America Bulletin 114(9): 1131-1142, DOI 10.1130/0016-7606(2002)114.

Hetzel R, Niedermann S, Tao MX, Kubik PW and Strecker MR, 2006. Climatic versus tectonic control on river incision at the margin of 
NE Tibet: ${ }^{10} \mathrm{Be}$ exposure dating of river terraces at the mountain front of the Qilian Shan. Journal of Geophysical Research 111, F03012. DOI 10.1029/2005jf000352.

Huntley DJ and Lamothe M, 2001. Ubiquity of anomalous fading in Kfeldspars and the measurement and correction for it in optical dating. Canadian Journal of Earth Sciences 38(7): 1093-1106, DOI 10.1139/cjes-38-7-1093.

Jacobs Z, Duller GAT and Wintle AG, 2006. Interpretation of single grain $\mathrm{D}_{\mathrm{e}}$ distributions and calculation of $\mathrm{D}_{\mathrm{e}}$ Radiation Measurements 41(3): 264-277, DOI 10.1016/j.radmeas.2005.07.027.

Jacobs Z, Wintle AG, Roberts RG and Duller GAT, 2008. Equivalent dose distributions from single grains of quartz at Sibudu, South Africa: context, causes and consequences for optical dating of archaeological deposits. Journal of Archaeological Science 35(7): 1808-1820, DOI 10.1016/j.jas.2007.11.027.

Jain M, Murray AS and Bøtter-Jensen L, 2004. Optically stimulated luminescence dating: How significant is incomplete bleaching in fluvial environments. Quaternaire 15(1-2): 143-157.

Kadinsky-Cade K, Reilinger R and Isacks B, 1985. Surface deformation associated with the November 23, 1977, Caucete, Argentina, earthquake sequence. Journal of Geophysical Research 90(B14): 2691-2700, DOI 10.1029/JB090iB14p12691.

Kurth G, Phillips FM, Reheis MC, Redwine JL and Paces JB, 2011. Cosmogenic nuclide and uranium-series dating of old, high shorelines in the western Great Basin, USA. Geological Society of America Bulletin 123(3-4): 744-768, DOI 10.1130/b30010.1.

Lauer T, Frechen M, Hoselmann C and Tsukamoto S, 2010. Fluvial aggradation phases in the Upper Rhine Graben - New insights by quartz OSL dating. Proceedings of the Geologists' Association 121: 154-161, DOI 10.1016/j.pgeola.2009.10.006.

Madsen AT, Duller GAT, Donnelly JP, Roberts HM and Wintle AG, 2009. A chronology of hurricane landfalls at Little Sippewissett Marsh, Massachusetts, USA, using optical dating. Geomorphology 109(1-2): 36-45, DOI 10.1016/j.geomorph.2008.08.023.

Magee JW, Miller GH, Spooner NA, Questiaux DG, McCulloch MT and Clark PA, 2009. Evaluating Quaternary dating methods: Radiocarbon, U-series, luminescence, and amino acid racemization dates of a late Pleistocene emu egg. Quaternary Geochronology 4(2): 84-92, DOI 10.1016/j.quageo.2008.10.001

Markgraf V, 1989. Palaeoclimates in central and south America since 18,000 BP based on pollen and lake-level records. Quaternary Science Reviews 8(1): 1-24, DOI 10.1016/0277-3791(89)90018-8.

McCormac FG, Hogg AG, Blackwell PG, Buck CE, Higham TFG and Reimer PJ, 2004. SHCal04 Southern Hemisphere calibration, 011.0 cal kyr BP. Radiocarbon 46(3): 1087-1092.

Mejdahl V, 1979. Thermoluminescence dating - beta-dose attenuation in quartz grains. Archaeometry 21(1): 61-72, DOI 10.1111/j.14754754.1979.tb00241.x.

Mingorance F, 2006. Morfometría de la escarpa de falla histórica identificada al norte del cerro $\mathrm{La} \mathrm{Cal}$, zona de falla $\mathrm{La} \mathrm{Cal}$, Mendoza (Morphometry of the historic fault scarp identfied north of Cerro La Cal, La Cal Fault Zone, Mendoza). Revista de la Asociación Geológica Argentina 61(4): 620-638 (in Spanish; Abstract in English)

Murray AS and Roberts RG, 1997. Determining the burial time of single grains of quartz using optically stimulated luminescence. Earth and Planetary Science Letters 152(1-4): 163-180, DOI 10.1016/S0012-821X(97)00150-7.

Murray AS and Wintle AG, 2000. Luminescence dating of quartz using an improved single-aliquot regenerative-dose protocol. Radiation Measurements 32(1): 57-73, DOI 10.1016/S1350-4487(99)00253$\mathrm{X}$.

Murray AS and Olley JM, 2002. Precision and accuracy in the optically stimulated luminescence dating of sedimentary quartz: a status review. Geochronometria 21: 1-16.

Murray AS and Wintle AG, 2003.The single aliquot regenerative dose protocol: potential for improvements in reliability. Radiation Measurements 37(4-5): $377-381$, DOI $10.1016 / \mathrm{S} 1350-$ 4487(03)00053-2.
Niedermann S, 2002. Cosmic-Ray-Produced Noble Gases in Terrestrial Rocks: Dating Tools for Surface Processes. Reviews in Mineralogy and Geochemistry 47: 731-784.

Nissen E, Walker RT, Bayasgalan A, Carter A, Fattahi M, Molor E, Schnabel C, West AJ and Xu S, 2009. The late Quaternary sliprate of the Har-Us-Nuur fault (Mongolian Altai) from cosmogenic ${ }^{10} \mathrm{Be}$ and luminescence dating. Earth and Planetary Science Letters 286(3-4): 467-478, DOI 10.1016/j.eps1.2009.06.048.

Olgiati S and Ramos VA, 2003. Neotectónica Cuarternaria en el Anticlinal Borbollón, Provincia de Mendoza - Argentina (Quaternary neotectonics in the Borbollón anticline, Mendoza province - Argentina). $10^{\circ}$ Congreso Geológico Chileno $11 \mathrm{pp}$. (in Spanish).

Olley JM, Murray AS and Roberts RG, 1996. The effects of disequilibria in the uranium and thorium decay chains on burial dose rates in fluvial sediments. Quaternary Science Reviews 15(7): 751-760, DOI 10.1016/0277-3791(96)00026-1.

Olley JM, Caitcheon GG and Roberts RG, 1999. The origin of dose distributions in fluvial sediments, and the prospect of dating single grains from fluvial deposits using optically stimulated luminescence. Radiation Measurements 30(2): 207-217, DOI 10.1016/S1350-4487(99)00040-2.

Owen LA, Bright J, Finkel RC, Jaiswal MK, Kaufman DS, Mahan S, Radtke U, Schneider JS, Sharp W, Singhvi AK and Warren CN, 2007. Numerical dating of a Late Quaternary spit-shoreline complex at the northern end of Silver Lake playa, Mojave Desert, California: A comparison of the applicability of radiocarbon, luminescence, terrestrial cosmogenic nuclide, electron spin resonance, Useries and amino acid racemization methods. Quaternary International 166(1): 87-110, DOI 10.1016/j.quaint.2007.01.001.

Porat N, Wintle AG, Amit R and Enzel Y, 1996. Late Quaternary Earthquake Chronology from Luminescence Dating of Colluvial and Alluvial Deposits of the Arava Valley, Israel. Quaternary Research 46(2): 107-117, DOI 10.1006/qres.1996.0051.

Porat N, Duller GAT, Amit R, Zilberman E and Enzel Y, 2009. Recent faulting in the southern Arava, Dead Sea Transform: Evidence from single grain luminescence dating. Quaternary International 199(1-2): 34-44, DOI 10.1016/j.quaint.2007.08.039.

Porat N, Amit R, Enzel Y, Zilberman E, Avni Y, Ginat H and Gluck D, 2010. Abandonment ages of alluvial landforms in the hyperarid Negev determined by luminescence dating. Journal of Arid Environments 74(7): 861-869, DOI 10.1016/j.jaridenv.2009.10.018.

Prescott JR and Stephan LG, 1982. The contribution of cosmic radiation to the environmental dose for thermoluminescence dating. Latitude, altitude and depth dependence. PACT 6: 17-25.

Prescott JR and Hutton JT, 1988. Cosmic ray and gamma ray dosimetry for TL and ESR. International Journal of Radiation Applications and Instrumentation. Part D. Nuclear Tracks and Radiation Measurements 14(1-2): 223-227, DOI 10.1016/13590189(88)90069-6.

Prescott JR and Hutton JT, 1994. Cosmic ray contributions to dose rates for luminescence and ESR dating: Large depths and long-term time variations. Radiation Measurements 23(2-3): 497-500, DOI 10.1016/1350-4487(94)90086-8.

Preusser F, Geyh MA and Schlüchter C, 2003. Timing of Late Pleistocene climate change in lowland Switzerland. Quaternary Science Reviews 22(14): 1435-1445, DOI 10.1016/s0277-3791(03)00127-

Preusser F, Hajdas I and Ivy-Ochs S, 2008. Recent progress in Quaternary dating methods. Eiszeitalter und Gegenwart 57(1-2), E. Schweizerbart'sche Verlagsbuchhandlung, Stuttgart: 262pp.

Reimann T, Tsukamoto S, Naumann M and Frechen M, 2011. The potential of using K-rich feldspars for optical dating of young coastal sediments - a test case from Darss-Zingst peninsula (southern Baltic Sea coast). Quaternary Geochronology 6(2): 207-222, DOI 10.1016/j.quageo.2010.10.001.

Rittenour TM, 2008. Luminescence dating of fluvial deposits: applications to geomorphic, palaeoseismic and archaeological research. Boreas 37(4): 613-635, DOI 10.1111/j.1502-3885.2008.00056.x.

Roberts RG, Galbraith RF, Olley JM, Yoshida H and Laslett GM, 1999. Optical dating of single and multiple grains of quartz from Jinmi- 
um rock shelter, northern Australia, part 2, Results and implications. Archaeometry 41(2): 365-395, DOI 10.1111/j.14754754.1999.tb00988.x.

Roberts HM and Wintle AG, 2001. Equivalent dose determinations for polymineralic fine-grains using the SAR protocol: application to a Holocene sequence of the Chinese Loess Plateau. Quaternary Science Reviews 20(5-9): 859-863, DOI 10.1016/S02773791(00)00051-2.

Robinson RAJ, Spencer JQG, Strecker MR, Richter A and Alonso RN, 2005. Luminescence dating of alluvial fans in intramontane basins of NW Argentina. In: Harvey AM, Mather AE and Stokes M, eds, Alluvial Fans: Geomorphology, Sedimentology, Dynamics. Geological Society Special Publication, London: 153-168 pp.

Rodnight H, 2008. How many equivalent dose values are needed to obtain a reproducible distribution? Ancient TL 26(1): 3-9.

Rodnight H, Duller GAT, Wintle AG and Tooth S, 2006. Assessing the reproducibility and accuracy of optical dating of fluvial deposits. Quaternary Geochronology 1(2): 109-120, DOI 10.1016/j.quageo.2006.05.017.

Salomon E, 2010. Paleoseismic investigations at the Cal thrust fault, Mendoza, Argentina. M.Sc. thesis, University of Münster, Münster, Germany, $43 \mathrm{pp}$.

Sancho C, Peña JL, Rivelli F, Rhodes E and Muñoz A, 2008. Geomorphological evolution of the Tilcara alluvial fan (Jujuy Province, NW Argentina): Tectonic implications and palaeoenvironmental considerations. Journal of South American Earth Sciences 26(1): 68-77, DOI 10.1016/j.jsames.2008.03.005.

Schmidt S, Hetzel R, Kuhlmann J, Mingorance F and Ramos VA, 2011a. A note of caution on the use of boulders for exposure dating of depositional surfaces. Earth and Planetary Science Letters 302(1-2), 60-70, DOI 10.1016/j.epsl.2010.11.039.

Schmidt S, Hetzel R, Mingorance F and Ramos VA, 2011b. Coseismic displacements and Holocene slip rates for two active thrust faults at the mountain front of the Andean Precordillera $\left(\sim 33^{\circ} \mathrm{S}\right)$. Tectonics 30, TC5011, DOI 10.1029/2011TC002932.

Sepúlveda E, 2001. Hoja Geológica 3369-II, Mendoza. Provincias de Mendoza y San Juan (Geological map 3369-II, Mendoza. Mendoza and San Juan province). Instituto de Geología y Recursos Minerales, Servicio Geológico Minero Argentino, Boletín 252, Buenos Aires: 55pp (in Spanish).
Siame LL, Bellier O, Sébrier M, Bourlès DL, Leturmy P, Perez M and Araujo M, 2002. Seismic hazard reappraisal from combined structural geology, geomorphology and cosmic ray exposure dating analyses: the Eastern Precordillera thrust system (NW Argentina). Geophysical Journal International 150(1): 241-260, DOI 10.1046/j.1365-246X.2002.01701.x.

Sohn MF, Mahan SA, Knott JR and Bowman DD, 2007. Luminescence ages for alluvial-fan deposits in Southern Death Valley: Implications for climate-driven sedimentation along a tectonically active mountain front. Quaternary International 166(1): 49-60, DOI 10.1016/j.quaint.2007.01.002.

Stokes S, Bray HE and Blum MD, 2001. Optical resetting in large drainage basins: tests of zeroing assumptions using single-aliquot procedures. Quaternary Science Reviews 20(5-9): 879-885, DOI 10.1016/S0277-3791(00)00045-7.

Stuiver M and Reimer PJ, 2011. CALIB Radiocarbon Calibration. http://radiocarbon.pa.qub.ac.uk/calib. (accessed May 2011).

Thomas PJ, Jain M, Juyal N and Singhvi AK, 2005. Comparison of single-grain and small-aliquot OSL dose estimates in $<3000$ years old river sediments from South India. Radiation Measurements 39(5): 457-469, DOI 10.1016/j.radmeas.2004.07.005.

Thomsen KJ, Jain M, Murray AS, Denby PM, Roy N and Bøtter-Jensen L, 2008. Minimizing feldspar OSL contamination in quartz UVOSL using pulsed blue stimulation. Radiation Measurements 43(26): 752-757, DOI 10.1016/j.radmeas.2008.01.020.

Toms PS, King M, Zarate MA, Kemp RA and Foit FF, 2004. Geochemical characterization, correlation, and optical dating of tephra in alluvial sequences of central western Argentina. Quaternary Research 62(1): 60-75, DOI 10.1016/j.yqres.2004.05.005.

Vandenberghe D, Hossain SM, De Corte F and Van den haute P, 2003. Investigations on the origin of the equivalent dose distribution in a Dutch coversand. Radiation Measurements 37(4-5): 433-439, DOI 10.1016/s1350-4487(03)00051-9.

Wallinga J, 2002. Optically stimulated luminescence dating of fluvial deposits: a review. Boreas 31(4): 303-322, DOI 10.1111/j.15023885.2002.tb01076.x.

Wallinga J, Murray AS and Bøtter-Jensen L, 2002. Measurement of the dose in quartz in the presence of feldspar contamination. Radiation Protection Dosimetry 101(1-4): 367-370.

Walker M, 2005. Quaternary dating methods. John Wiley \& Son Ltd, Chichester: 286pp. 